\title{
Effect of solar cell structure on the radiation resistance of an $\operatorname{lnP}$ solar cell
}

\author{
Halima Mazouz ${ }^{1}$, Abderrahmane Belghachi ${ }^{2}$, and Pierre-Olivier Logerais ${ }^{3, *}$ \\ ${ }^{1}$ Renewable energies department, Faculty of technology, Blida 1 university, Soumaa road, BP 270 Blida, Algeria \\ ${ }^{2}$ SDPL, Faculty of Science and Technology, University of Bechar, BP 417, Kenadsa Road, Bechar, Algeria \\ ${ }^{3}$ Université Paris-Est, CERTES, IUT de Sénart-Fontainebleau, 36 rue Georges Charpak, 77567 Lieusaint, France
}

\begin{abstract}
Effects of electron irradiation-induced deep level defects have been studied on both $\mathrm{n} / \mathrm{p}$ and $\mathrm{p} / \mathrm{n}$ Indium Phosphide (InP) solar cells with very thin emitters. The simulation results reveal that the $\mathrm{n} / \mathrm{p}$ structure offers a somewhat better short-circuit current and that the $\mathrm{p} / \mathrm{n}$ structure renders an improved opencircuit voltage, not only before electron irradiation but also after $1 \mathrm{MeV}$ electron irradiation with $5 \times 10^{15}$ electrons per $\mathrm{cm}^{2}$ fluence. Further, the calculated findings highlight that the $\mathrm{n} / \mathrm{p}$ solar cell structure is more resistant than that of a $\mathrm{p} / \mathrm{n}$ structure.
\end{abstract}

\section{Introduction}

Research into space solar cells has progressed rapidly over the last couple of decades. The fundamental objectives for developing space solar cells are to uplift their high efficiency and radiation resistance and in this framework, Gallium Arsenide (GaAs) cells have been found to be more promising than silicon ( $\mathrm{Si}$ ) cells for space applications $[1,2]$. Developments have also been focused on Indium Phosphide solar cells (InP) for the reason that their radiation tolerance surpasses that of the GaAs and $\mathrm{Si}$ ones as reported in variant studies [1, 3, 4]. Moreover, they have several other advantages like a high-efficiency, a thin-film structure, a high-temperature operation and a simple cell structure $[5,6]$. InP cells appear then as very attractive materials for space solar cells as of late, elevated conversion efficiencies exceeding $29.2 \%$ (AM0 at $25^{\circ} \mathrm{C}$ ) have been achieved [7]. Also, it has been demonstrated that InP solar cells exhibit relatively low levels of performance degradation for both proton and electron irradiation $[1,7]$.

The development efforts of InP photovoltaic cells have been focused on the $n / p$ structure under AM0 conditions and little has been published on the performance of the $\mathrm{p} / \mathrm{n}$ structure [8-12]. Table 1 summarizes the designs, the parameters of the emitters and bases, and the reported performances of three InP solar cells in space conditions (AM0, $1.35 \mathrm{~kW} . \mathrm{m}^{-2}$, $\left.25^{\circ} \mathrm{C}\right)$. As can be seen, Sharps et al. found that $\mathrm{n} / \mathrm{p}$ solar cells have heightened open-circuit voltage $\left(V_{o c}\right)$ and short-circuit current density $\left(J_{s c}\right)$ regarding the $\mathrm{p} / \mathrm{n}$ ones [11]. Nevertheless, Jain et al. shed into light that $\mathrm{p} / \mathrm{n}$ solar cells achieve greater efficiency in comparison with $\mathrm{n} / \mathrm{p}$ solar cells, owing to more elevated $V_{o c}$ even though the value of $J_{s c}$ is somewhat lower than for the $\mathrm{n} / \mathrm{p}$ structure [12].

Since InP solar cells are promising for space applications, the objective of this paper is twofold: (i) compare the expected performance of $n / p$ and $p / n$ indium phosphide solar cells under space conditions, and (ii) model the effects of $1 \mathrm{MeV}$ electron irradiation on InP solar cells.

\section{Numerical modeling}

Numerical simulations of InP solar cells have been carried out by using the finite element method in order to solve Poisson equation (1) coupled with the equations of continuity for both the electrons (2) and the holes (3):

$$
\begin{aligned}
& -\nabla .(\varepsilon . \nabla \psi)=q(p-n+N) \\
& d J_{n} / d x=-q\left(G_{o p t}-R_{S R H}\right) \\
& d J_{p} / d x=q\left(G_{o p t}-R_{S R H}\right)
\end{aligned}
$$

where the three dependent variables are $\psi$ the electrostatic potential, $q$ the elementary charge, $n$ and $p$ the electron and the hole concentrations respectively. $J_{n}$ and $J_{p}$ are the electron and the hole conduction current densities. $\varepsilon$ is the permittivity and $N$ is the fixed charge associated with ionized donors.

In equations (2) and (3), $R_{S R H}$ describes the nonradiative recombination mechanisms such as SchockleyRead-Hall, Auger and surface recombinations.

* Corresponding author: pierre-olivier.logerais@u-pec.fr 
Table 1. Designs and reported performances of InP solar cells [10-12].

\begin{tabular}{|c|c|c|c|c|c|}
\hline Group & Vilela et al. [10] & \multicolumn{2}{|c|}{ Sharps et al. [11] } & \multicolumn{2}{|c|}{ Jain et al. [12] } \\
\hline Design & $\mathrm{p} / \mathrm{n}$ & $\mathrm{n} / \mathrm{p}$ & $\mathrm{p} / \mathrm{n}$ & $\mathrm{n} / \mathrm{p}$ & $\mathrm{p} / \mathrm{n}$ \\
\hline Emitter doping $\left(\mathrm{cm}^{-3}\right)$ & $2 \times 10^{18}$ & \multicolumn{2}{|c|}{$5 \times 10^{16}$} & \multicolumn{2}{|c|}{$1 \times 10^{18}$} \\
\hline Emitter thickness $(\mu \mathrm{m})$ & 0.08 & \multicolumn{2}{|c|}{0.05} & 0.02 & 0.15 \\
\hline Base doping $\left(\mathrm{cm}^{-3}\right)$ & $5 \times 10^{17}$ & \multicolumn{2}{|c|}{$5 \times 10^{16}$} & \multicolumn{2}{|c|}{$1 \times 10^{17}$} \\
\hline Base thickness $(\mu \mathrm{m})$ & 1.5 & \multicolumn{2}{|c|}{3} & \multicolumn{2}{|c|}{5} \\
\hline$J_{s c}\left(\mathrm{~mA} \cdot \mathrm{cm}^{-2}\right)$ & 21.5 & 28.87 & 28.68 & 42.37 & 41.49 \\
\hline$V_{o c}(\mathrm{~V})$ & 0.803 & 0.848 & 0.814 & 0.941 & 0.997 \\
\hline$F F$ & 0.77 & 0.779 & 0.814 & 0.863 & 0.869 \\
\hline$\eta(\%)$ & 10.5 & 14.1 & 13.9 & 25.1 & 26.2 \\
\hline
\end{tabular}

Table 2. Parameters of the InP materials in the model [13,14].

\begin{tabular}{lcc}
\hline Parameter & Symbol & Value \\
\hline Elementary charge & $q$ & $1.602 \times 10^{-19} \mathrm{C}$ \\
Room temperature & $T$ & $300 \mathrm{~K}$ \\
Boltzmann constant & $k$ & $1.38 \times 10^{-23} \mathrm{~J} \cdot \mathrm{K}^{-1}$ \\
Gap energy & $E_{g}$ & $1.35 \mathrm{eV}$ \\
Relative permittivity & $\varepsilon_{r}$ & 12.6 \\
Intrinsic concentration & $n_{i}$ & $1.2 \times 10^{7} \mathrm{~cm}^{-3}$ \\
Effective density of state in the conduction band & $N_{c}$ & $5.7 \times 10^{17} \mathrm{~cm}^{-3}$ \\
Effective density of state in the valence band & $N_{v}$ & $1.1 \times 10^{19} \mathrm{~cm}^{-3}$ \\
Electron mobility & $\mu_{n}$ & $5900 \mathrm{~cm}^{2} . \mathrm{V}^{-1} \cdot \mathrm{s}^{-1}$ \\
Hole mobility & $\mu_{p}$ & $150 \mathrm{~cm}^{2} \cdot \mathrm{V}^{-1} \cdot \mathrm{s}^{-1}$ \\
Electron thermal velocity & $V_{t h n}$ & $3.9 \times 10^{5} \mathrm{~m}^{-1}$ \\
Hole thermal velocity & $V_{t h p}$ & $1.7 \times 10^{5} \mathrm{~m}^{-1}$ \\
Electron lifetime & $\tau_{n}$ & $0.73 \mathrm{~ns}^{-1}$ \\
Hole lifetime & $\tau_{p}$ & $151.5 \mathrm{~ns}$ \\
Radiative recombination coefficient & $\tau_{\text {rad }}$ & $1.2 \times 10^{-10} \mathrm{~cm}^{3} . \mathrm{s}^{-1}$ \\
Surface recombination coefficient & $\tau_{s}$ & $9 \times 10^{-31} \mathrm{~cm}^{6} . \mathrm{s}^{-1}$ \\
\hline
\end{tabular}

The InP cell is exposed to sunlight outside the atmosphere. The AM0 conditions corresponding to the characteristics of the sun radiation level before the passage of sunlight through the atmosphere of the earth with an integral power of $1.35 \mathrm{~kW} . \mathrm{m}^{-2}$ have hence been considered along with an optical generation $G_{o p t}$ for the free carriers:

$$
G_{o p t}=(1-R) \cdot \alpha(\lambda) \cdot \phi \cdot \exp (-\alpha(\lambda) x)
$$

where $R$ is the reflectivity of the front contact, $\alpha(\lambda)$ is the absorption coefficient dependent on the wavelength $\lambda$, $\phi$ is the photon flux and $x$ is the depth in the semiconductor along the propagation direction.

The parameters of the materials listed in Table 2 are used in the numerical simulations [13, 14]. The material properties of the $\mathrm{n} / \mathrm{p}$ structure are detailed in Table 3 . Alike properties are utilized in the case of the $\mathrm{p} / \mathrm{n}$ configuration except for the back surface recombination velocity $\left(10^{7} \mathrm{~cm} \cdot \mathrm{s}^{-1}\right)$, the emitter diffusion length $(2 \mu \mathrm{m})$ and the base diffusion length $(5 \mu \mathrm{m})$. Values listed in Table 3 are reported from the literature [3, 9, 15]. The geometries of both the $n / p$ and the $p / n$ junctions with their meshes were realized in the same manner. The example of the $n / p$ structure is depicted in Figure 1. Both the meshes contain 860 nodes and 1592 elements. The minimum quality of the elements is of 0.8308 .
Table 3. Parameters of the emitter and the base materials for the optimal design of a $\mathrm{n} / \mathrm{p}$ InP solar cell $[3,9,15]$.

\begin{tabular}{lcc}
\hline Parameter & Emitter & Base \\
\hline Thickness $(\mu \mathrm{m})$ & 0.08 & 5 \\
Doping $\left(\mathrm{cm}^{-3}\right)$ & $5 \times 10^{17}$ & $10^{18}$ \\
Front surface recombination velocity $\left(\mathrm{cm} . \mathrm{s}^{-1}\right)$ & $10^{4}$ & - \\
Surface recombination velocity $\left(\mathrm{cm} . \mathrm{s}^{-1}\right)$ & - & $10^{5}$ \\
Electron diffusion length $(\mu \mathrm{m})$ & 0.1 & - \\
Hole diffusion length $(\mu \mathrm{m})$ & - & 20 \\
\hline
\end{tabular}

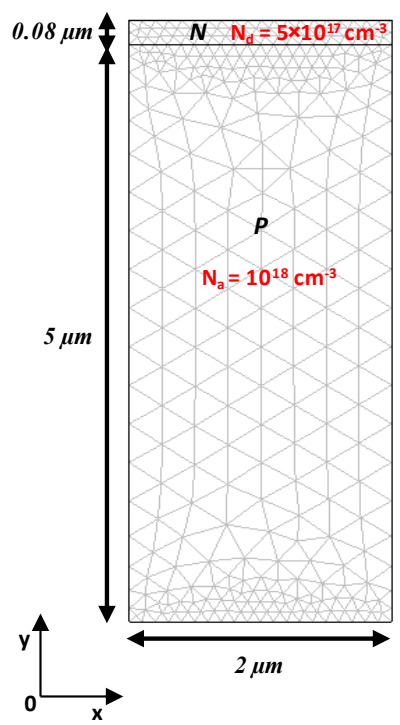

Fig. 1. Geometry of the solar $\mathrm{n} / \mathrm{p}$ junction with its mesh. 
Table 4. Electron and hole traps observed by Deep Level Transient Spectroscopy (DLTS) in an InP solar cell irradiated by $1 \mathrm{MeV}$ electrons $[16,17]$.

\begin{tabular}{lcccc}
\hline \multicolumn{2}{c}{ Trap designation } & $\begin{array}{c}\text { Trap level } \\
(\mathbf{e V})\end{array}$ & $\begin{array}{c}\text { Capture cross section } \\
\mathbf{\sigma}\left(\mathbf{c m}^{\mathbf{2}}\right)\end{array}$ & $\begin{array}{c}\text { Introduction rate } \\
(\mathbf{c m})\end{array}$ \\
\hline \multirow{4}{*}{ p-type } & H2 & 0.22 & $3 \times 10^{-17}$ & 0.02 \\
& H3 & 0.32 & $6 \times 10^{-16}$ & 0.82 \\
& H4 & 0.37 & $8 \times 10^{-16}$ & 1.2 \\
n-type & H5 & 0.52 & $5.5 \times 10^{-15}$ & 0.04 \\
& Ell & 0.76 & $2.9 \times 10^{-12}$ & 0.2 \\
\hline
\end{tabular}

Additionally, the solar cells are subjected to $1 \mathrm{MeV}$ electron irradiation which produces six hole traps and five electron traps in the p-type layer of an InP cell, while 16 electron and five hole traps appear in the n-type one $[16,17]$. The attention is drawn here to dominant traps for which a specific atomic structure has been proposed. Accordingly, H2, H3, H4, H5 and E11 traps which are due to phosphorus atom-electron collisions are accounted for in the present model [16]. Indeed, these centers act both as majority-carrier trap centers and recombination centers, and they also have higher introduction rates than the other centers. The trap levels, the capture cross sections and the introduction rates of these five electron and hole traps are shown in Table 4.

Numerical modeling is used as a means to simulate in 2 dimensions the operation modes of an InP solar cell with both $\mathrm{p} / \mathrm{n}$ and $\mathrm{n} / \mathrm{p}$ structures, and this is done with the presence of defects created by electron irradiation. The simulation is performed utilizing the electrostatic and diffusion modules of COMSOL Multiphysics.

\section{Results and discussion}

The numerical calculations were carried out to solve equations (1) to (4) in the case of both the $p / n$ and $n / p$ junctions, before irradiation and taking into consideration the modifications engendered by a $1 \mathrm{MeV}$ electron irradiation at $5 \times 10^{15}$ electrons per $\mathrm{cm}^{2}$ fluence on an InP solar cell. Figure 2 shows the calculated J(V) characteristics for the $\mathrm{n} / \mathrm{p}$ structure before and after electron irradiation of $1 \mathrm{MeV}$ whereas Figure 3 depicts them for the $\mathrm{p} / \mathrm{n}$ junction. Table 5 expresses the various cell performance parameters of the two solar cell structures $\mathrm{n} / \mathrm{p}$ and $\mathrm{p} / \mathrm{n}$ before and after electron irradiation.

Table 5 clearly discloses that prior to irradiation, the $\mathrm{n} / \mathrm{p}$ solar cell structure gives higher efficiencies compared to the $\mathrm{p} / \mathrm{n}$ structure due to a raised short-circuit current density $\left(J_{s c}\right)$. Thus, the usage of a $\mathrm{n} / \mathrm{p}$ structure appears attractive to reduce the area and the mass of the solar arrays deployed for space power applications.
Table 5. InP cell performance parameters before and after $1 \mathrm{MeV}$ electron irradiation at $5 \times 10^{15}$ electrons per $\mathrm{cm}^{2}$ fluence.

\begin{tabular}{lcccc}
\hline \multirow{2}{*}{ Output parameter } & \multicolumn{2}{c}{$\mathbf{n} / \mathbf{p}$} & \multicolumn{2}{c}{$\mathbf{p} / \mathbf{n}$} \\
& Before & After & Before & After \\
\hline$J_{s c}\left(\mathrm{~mA} \cdot \mathrm{cm}^{-2}\right)$ & 41.71 & 39.89 & 37.78 & 31.79 \\
$V_{o c}(\mathrm{~V})$ & 0.891 & 0.888 & 0.907 & 0.875 \\
$F F$ & 0.844 & 0.845 & 0.853 & 0.811 \\
$\eta(\%)$ & 23.24 & 22.19 & 21.66 & 16.73 \\
\hline
\end{tabular}

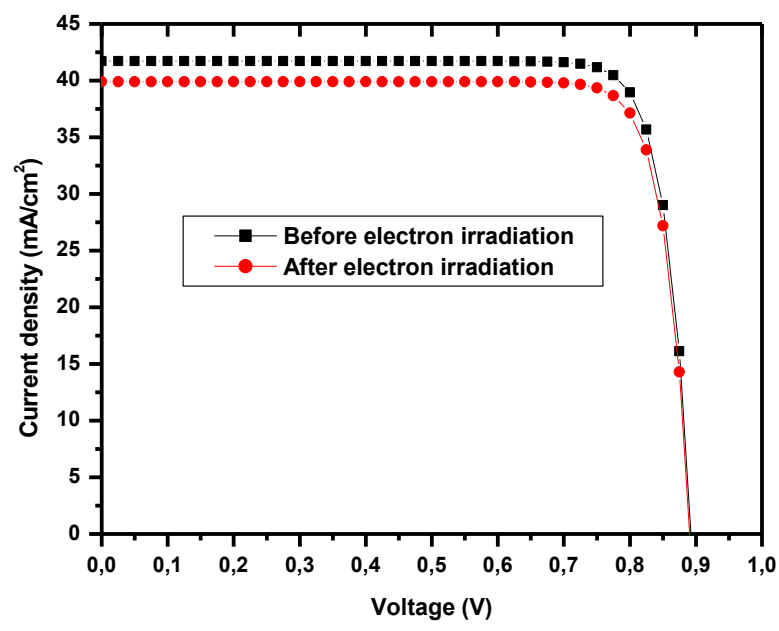

Fig. 2. $J(V)$ characteristics of the $\mathrm{n} / \mathrm{p}$ solar cell structure before and after $1 \mathrm{MeV}$ electron irradiation.

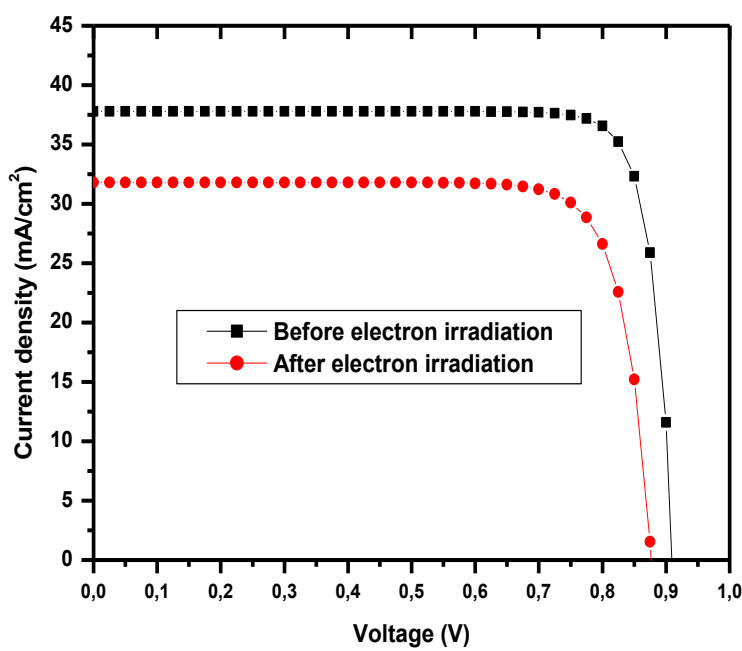

Fig. 3. $J(V)$ characteristics of the $\mathrm{p} / \mathrm{n}$ solar cell structure before and after $1 \mathrm{MeV}$ electron irradiation. 


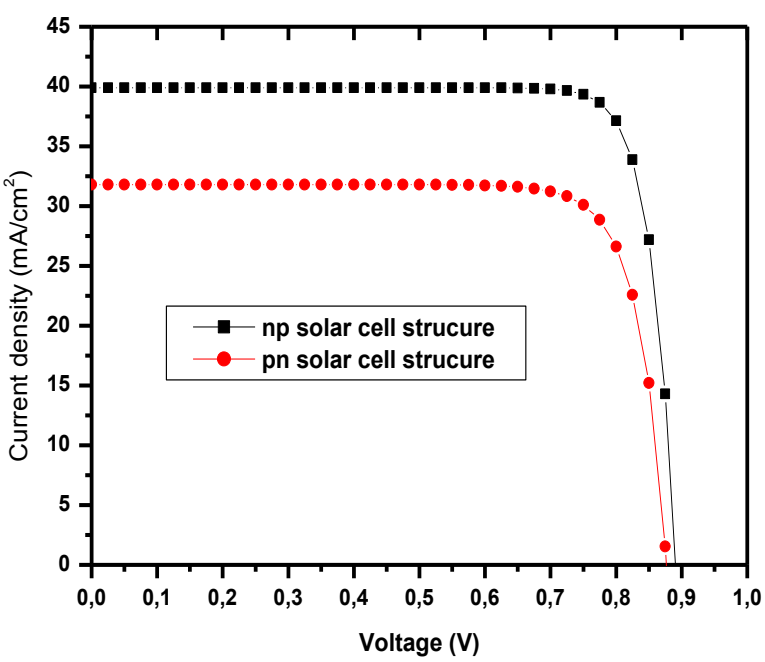

Fig. 4. Comparison of the $J(V)$ characteristics of the $n / p$ and the $\mathrm{p} / \mathrm{n}$ InP solar cell structures after electron irradiation.

Furthermore, it is found that the solar cell efficiencies are degraded for both the $\mathrm{n} / \mathrm{p}$ and the $\mathrm{p} / \mathrm{n}$ structure down to $22.19 \%$ and $16.73 \%$ respectively. $J_{s c}$ is more affected by electron irradiation for the $\mathrm{p} / \mathrm{n}$ structure with a decrease from 39.89 to $31.79 \mathrm{~mA} / \mathrm{cm}^{2}$ against 41.71 to $37.78 \mathrm{~mA} / \mathrm{cm}^{2}$ for the $\mathrm{n} / \mathrm{p}$ structure. However, the opencircuit voltage $V_{o c}$ is not altered for the $\mathrm{n} / \mathrm{p}$ solar cell structure while it is a bit more impacted for the $\mathrm{p} / \mathrm{n}$ one with a lessening from 0.907 to $0.875 \mathrm{~V}$. Besides, the fill factor $F F$ remains in the same magnitude although it gets slightly lower for the $\mathrm{p} / \mathrm{n}$ structure after electron irradiation.

In the $\mathrm{n} / \mathrm{p}$ solar cell structure, the $\mathrm{n}$-InP type layer is the emitter. The electron irradiation creates just one electron trap in this layer which could play the role of a doping level. Concerning the $\mathrm{p} / \mathrm{n}$ structure, the $\mathrm{p}$-InP type layer is the emitter. The electron irradiation creates four hole traps in this layer. The latter traps are considered as recombination centers. Thereby, they could be responsible for the serious degradation of the $J_{s c}$ and they surely raise the barrier potential at the $\mathrm{p} / \mathrm{n}$ interface. It is a fact that the open-circuit voltage of a solar cell is related to the barrier built-in voltage. Whereby, the elevation of the barrier potential compensates for the reduction of the $V_{o c}$ by electron irradiation.

For comparison, the $J(V)$ characteristic for both the $\mathrm{n} / \mathrm{p}$ and $\mathrm{p} / \mathrm{n}$ solar cell structures after the electron irradiation are plotted in Figure 4 . The $\mathrm{n} / \mathrm{p}$ solar cell structure is more resistant to radiation at $5 \times 10^{15}$ electrons per $\mathrm{cm}^{2}$ fluence than the $\mathrm{p} / \mathrm{n}$ solar cell structure as $J_{s c}$ is maintained at a $20 \%$ higher level. Obtained results are fairly in agreement with the findings in references [11, 19]. A possible explanation of the discrepancies is the type and the depth of the energy gaps of the defects created by irradiation for each solar cell structure. In the $\mathrm{p} / \mathrm{n}$ structure, the emitter layer has four defects $\left(\mathrm{H}_{2}, \mathrm{H}_{3}\right.$, $\mathrm{H} 4$ and H5), three of them happen to be deep level defects. In the $n / p$ structure, the emitter layer is the $n$ layer having only one defect (E11). The latter deep level defect has no significant influence on the initial $J(V)$ characteristic. This phenomenon can equally be observed in a GaAs based solar cell irradiated by electrons of 1 $\mathrm{MeV}$ [20].

\section{Conclusion}

Numerical simulation was used to compare the radiation resistance and the performances of $\mathrm{n} / \mathrm{p}$ and $\mathrm{p} / \mathrm{n}$ solar cell structures for an Indium Phosphide (InP) solar cell. It was noted that the optimum $\mathrm{n} / \mathrm{p}$ solar cell structure was more efficacious than the optimum $\mathrm{p} / \mathrm{n}$ solar cell structure on account of a larger short-current density which is in agreement with the outcomes of reference [11]. The same electron irradiation effects are observed on both the $n / p$ and the $p / n$ structures for the shortcurrent density. The present solar cell modeling not only predicts that the $\mathrm{n} / \mathrm{p}$ InP solar cell structure is more efficient than the $\mathrm{p} / \mathrm{n}$ one but also that the former is more radiation resistant. As a perspective for space applications, a modeling study of InP solar cells can be developed in order to deal with a $\mathrm{p}^{+} / \mathrm{nn}^{+}$structure having a very thin emitter layer, by reason that a slim emitter enhances the collection of carriers generated by high energy incident photons from the solar spectrum.

The authors are highly thankful to Mrs. Wilhelmina Logerais, a native English speaker, for proofreading this paper.

\section{References}

1. M. Yamaguchi, T. Hayashi, A. Ushirokawa, Y. Takahashi, M. Koubata, M. Hashimoto, H. Okazaki, T. Takamo, M. Ura, M. Ohmon, S. Ikegami, H. Arai, T. Orii, IEEE Conference on Photovoltaic Specialists, Kissimmee, FL, USA (1990) 1198-1202.

2. R.Y. Loo, G.S. Kamath, S.S. Li, IEEE Transactions on Electron Devices, 37, 2 (1990) 485-497.

3. G. Augustine, A. Rohatgi, N.M. Jokerst, IEEE Transactions on Electron Devices 39, 10 (1992) 2395-2400.

4. R.J. Walters, Proc. of 1994 IEEE $6^{\text {th }}$ International Conference on Indium Phosphide and Related Materials (IPRM), Santa Barbara, CA, USA (1994) 275-279.

5. P. Nubile, Solid-State Electronics 38, 1 (1995) 139142.

6. R. Mishra, O.D. Restrepo, A. Kumar, W. Windl, Journal of Materials Science 47, 21 (2012) 74827497.

7. M. Yamaguchi, Energy Procedia 15 (2012) 265274.

8. R.W. Hoffman, N.S. Fatemi, P.P. Jenkins, V.G. Weizer, M.A. Stan, S.A. Ringel, D.A. Scheiman, D.M. Wilt, D.J. Brinker, R.J. Walters, S.R. Messenger, Conference Record of the Twenty-Sixth IEEE Photovoltaic Specialists Conference 1997, Anaheim, CA, USA (1997) 815-818. 
9. L.C. Kilmer, A.M. Barnett, Conference Record of the Twenty-Second IEEE Photovoltaic Specialists Conference 1991, Las Vegas, NV, USA (1991) 347352.

10. M.F. Vilela, A. Freundlich, C. Monier, F. Newman, L. Aguilar, Journal of Crystal Growth 188 (1998) 311-316.

11. P.R. Sharps, M.L. Timmons, S.R. Messenger, H.L. Cotal, G.P. Summers, P.A. lles, Conference Record of the Twenty-Fifth IEEE Photovoltaic Specialists Conference 1996, Washington, DC, USA (1996) 175-178.

12. R.K. Jain, I. Weinberg, D.J. Flood. Comparison of $n p$ and pn Structures in Indium Phosphide Solar Cells (NASA Lewis Research Center, USA, 1991).

13. I. Weinberg, Solar Cells 31, 4 (1991) 331-348.

14. J.K. Luo, H. Thomas, N.M. Pearsall, LEOS 1992 Summer Topical Meeting Digest on Broadband Analog and Digital Optoelectronics, Optical Multiple Access Networks, Integrated Optoelectronics and Smart Pixels, Newport, RI, USA (1992) 589-592.
15. S.M. Sze, K.N. Kwok, Physics of semiconductor devices $\left(2^{\text {nd }}\right.$ edition, Wiley, New Jersey, USA, 1981).

16. H.Y. Tada, J.R. Carter, B.E. Anspaugh, R.G. Downing, Solar Cell Radiation Handbook (JPL publication, 1977).

17. G. Augustine, A. Rohatgi, N.M. Jokerst, Proc. of Third International Conference Indium Phosphide and Related Materials, Cardiff, UK (1991) 60-63.

18. R.J. Walters, C.J. Keavney, S.R. Messenger, G.P. Summers, E.A. Burke, Conference Record of the Twenty-Second IEEE Photovoltaic Specialists Conference 1991, Las Vegas, NV, USA (1991) 1588-1592.

19. S.J. Wojtczuk, N.H. Karam, P. Gouker, P. Colter, S.M. Vernon, G.P. Summers, R.L. Walters, R. Statler, Proc. of 1994 IEEE $1^{\text {st }}$ World Conference on Photovoltaic Energy Conversion - WCPEC (A Joint Conference of PVSC, PVSEC and PSEC), Waikoloa, HI (1994) 705-1708.

20. H. Mazouz, P.O. Logerais, A. Belghachi, O. Riou, F. Delaleux, J.F. Durastanti, International Journal of Hydrogen Energy 40, 39 (2015) 13857-13865. 